\title{
First wastewater surveillance-based city zonation for effective COVID-19 pandemic preparedness powered by early warning: A study of Ahmedabad, India
}

\footnotetext{
Manish Kumar $^{1,2}$, Madhvi Joshi ${ }^{3}$, Anil V. Shah ${ }^{4}$, Vaibhav Srivastava ${ }^{1}$, Shyamnarayan Dave ${ }^{5}$

${ }^{1}$ Discipline of Earth Science, Indian Institute of Technology Gandhinagar, Gujarat 382 355, India

${ }^{2}$ Kiran C Patel Centre for Sustainable Development, Indian Institute of Technology Gandhinagar, Gujarat, India

${ }^{3}$ Gujarat Biotechnology Research Centre (GBRC), Sector- 11, Gandhinagar, Gujarat 382 011, India

${ }^{4}$ Gujarat Pollution Control Board, Paryavaran Bhavan, Sector-10A, Gandhinagar, Gujarat 382010, India

${ }^{5}$ United Nations Children's Fund, Gujarat State Office, Gandhinagar, Sector 20, Gandhinagar, Gujarat 382021, India

*Corresponding Author:

Manish Kumar | Ph.D, FRSC, JSPS, WARI

Discipline of Earth Science | IIT Gandhinagar | India in

Email: manish.kumar@iitgn.ac.in; manish.env@gmail.com

Google Scholar I Research Gate / ORCID / Twitter / SCOPUS
} 


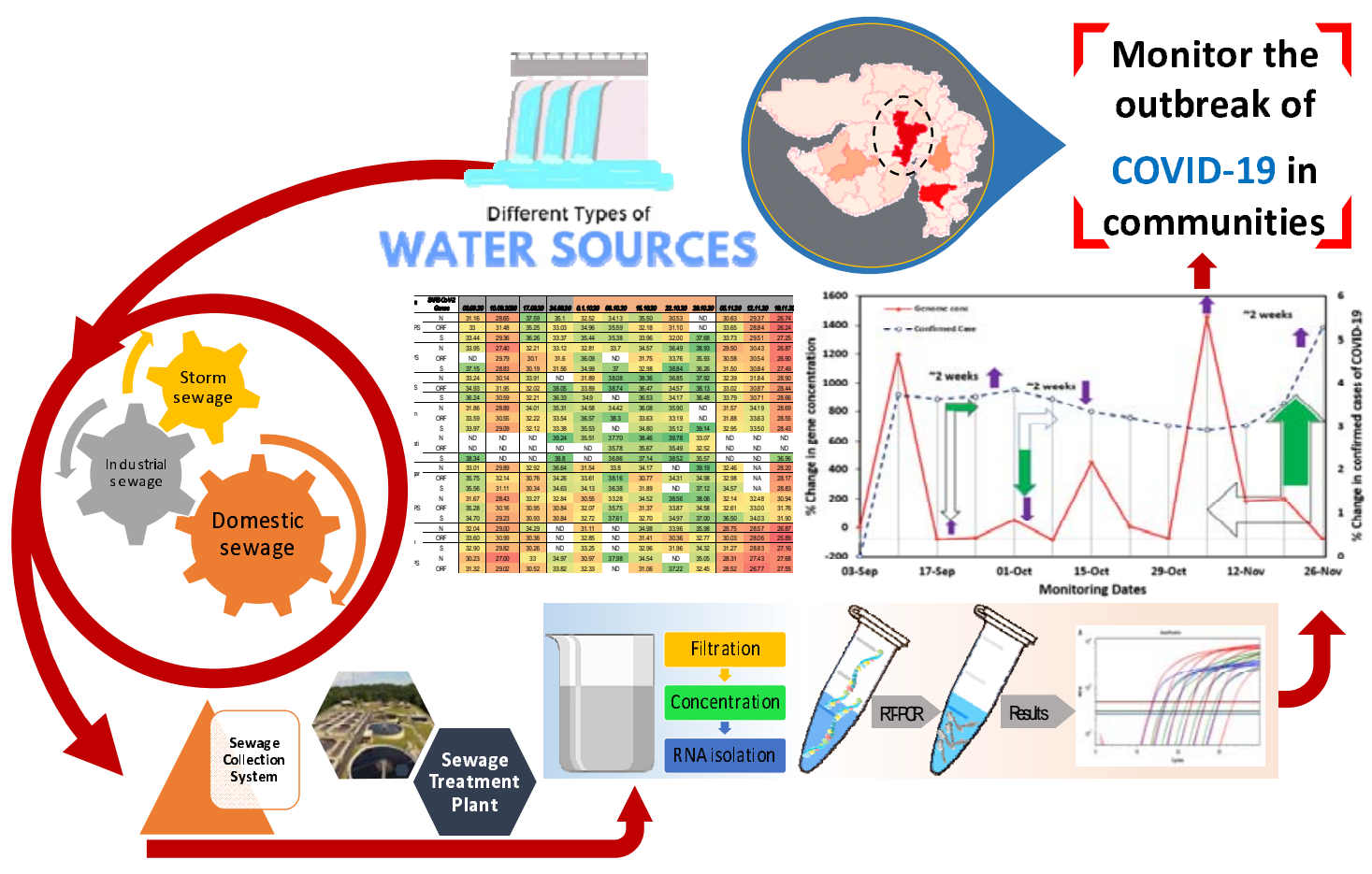

\section{Highlights}

- Wastewater surveillance-based city zonation is effective for COVID-19 pandemic preparedness.

- Three months variation of SARS-CoV-2 RNA in the wastewaters of Ahmedabad, India is presented.

- Wastewater monitoring offers a lead of $\sim 2$ weeks to realize and manage the pandemic situation.

- Mapping powered by early warning can strengthen the preparedness of community.

- WBE based COVID-19 surveillance is a high end technique for identifying hotspots on city scale. 
medRxiv preprint doi: https://doi.org/10.1101/2021.03.18.21253898; this version posted March 20, 2021. The copyright holder for this preprint (which was not certified by peer review) is the author/funder, who has granted medRxiv a license to display the preprint in perpetuity.

All rights reserved. No reuse allowed without permission.

\begin{abstract}
Following the proven concept, capabilities, and limitations of detecting the RNA of Severe Acute Respiratory Coronavirus 2 (SARS-CoV-2) in wastewater, it is pertinent to understand the utility of wastewater surveillance data on various scale. In the present work, we put forward the first wastewater surveillance-based city zonation for effective COVID-19 pandemic preparedness. A three-month data of Surveillance of Wastewater for Early Epidemic Prediction (SWEEP) was generated for the world heritage city of Ahmedabad, Gujarat, India. In this expedition, one hundred sixteen wastewater samples were analyzed to detect SARSCoV-2 RNA, from September $3^{\text {rd }}$ to November $26^{\text {th }}, 2020$. A total of 111 samples were detected with at least two out of three SARS-CoV-2 genes (N, ORF 1ab, and S). Monthly variation depicted a significant decline in all three gene copies in October compared to September 2020, followed by a sharp increment in November 2020. Correspondingly, the descending order of average genome concentration was: November ( 10729 copies/ L) > September ( 3047 copies/L) > October ( 454 copies/ L). Monthly variation of SARS-CoV-2 RNA in the wastewater samples may be ascribed to a decline of $19.3 \%$ in the total number of active cases in October 2020 and a rise of $1.82 \%$ in November 2020. Also, the monthly recovery rate of patients was 16.61, 19.31, and 15.58\% in September, October, and November 2020, respectively. The percentage change in the genome concentration was observed in the lead of 1-2 weeks with respect to the provisional figures of confirmed cases. SWEEP data-based city zonation was matched with the heat map of the overall COVID-19 infected population in Ahmedabad city, and month-wise effective RNA concentration variations are shown on the map. The results expound on the potential of WBE surveillance of COVID-19 as a city zonation tool that can be meaningfully interpreted, predicted, and propagated for community preparedness through advance identification of COVID-19 hotspots within a given city.
\end{abstract}

Keywords: Wastewater based epidemiology (WBE); COVID-19; SARS-CoV-2; Pandemic; Surveillance 
medRxiv preprint doi: https://doi.org/10.1101/2021.03.18.21253898; this version posted March 20, 2021. The copyright holder for this preprint (which was not certified by peer review) is the author/funder, who has granted medRxiv a license to display the preprint in perpetuity.

All rights reserved. No reuse allowed without permission.

\section{Introduction}

The contagious severe acute respiratory syndrome coronavirus 2 (SARS-CoV-2), responsible for the coronavirus pandemic, has infected 11 million people in India alone by February $22^{\text {nd }}, 2021$ (WHO, 2020). A large number of asymptomatic patients exerted a never seen before challenges over the actual estimation of disease spread based on clinical surveillance (Rimoldi et al., 2020; Medema et al., 2020). Earlier studies suggested that $18-45 \%$ of patients do not have signs of infection with COVID-19 but are capable of spreading the disease and pose an adverse impact on the actual containment of the disease (Lavezzo et al., 2020; Yang et al., 2020; Mizumoto et al., 2020; Nishiura et al., 2020). As upto 67\% of infected people showed SARS-CoV-2 presence in feces (Chan et al., 2020; Cheung et al., 2020; Parasa et al., 2020; Wong et al., 2020), alternative approaches such as wastewater-based epidemiology (WBE) surveillance has gained loads of recognition as a viable option that can provide early warning of the upcoming prevalence of the disease within a community (Tran et al., 2020; Hata et al., 2021; Kumar et al., 2021a, b,). One of the advantages of WBE is that wastewater contains feces from a huge number of people. Therefore, it may require a far fewer number samples and less labor than clinical testing to know the presence of infected persons in the area (Prevost et al., 2015). However, the sensitivity of WBE for SARS-CoV-2 detection is comparatively less than norovirus, presumably due to the low SARS-CoV-2 load in the patient's fecal matter and it's enveloped nature (Hata et al., 2020). Also, to evaluate WBE's potential as an early prediction tool for COVID-19 pandemic, it is essential to explore the correlation between the SARS-CoV-2 genetic load in wastewater and the number of cases at the district level in each country.

Overall, following the proven concept and capabilities of detecting the RNA of Severe Acute Respiratory Coronavirus 2 (SARS-CoV-2) in wastewater, several limitations and bottlenecks have been put forward towards its practical applicability (Zhu et al., 2021). On the other hand, there is a dire need for time-series data of SARS-CoV-2 RNA concentration in the wastewater that can be matched with the actual clinical survey data to confirm the utility and predictability of wastewater surveillance. This is also imperative for the adaptation of the Surveillance of Wastewater for Early Epidemic Prediction (SWEEP) on the policy level, 
medRxiv preprint doi: https://doi.org/10.1101/2021.03.18.21253898; this version posted March 20, 2021. The copyright holder for this preprint (which was not certified by peer review) is the author/funder, who has granted medRxiv a license to display the preprint in perpetuity.

All rights reserved. No reuse allowed without permission.

which has been for some reason still delayed in the major parts of the globe (Tiwari et al., 2021). There has also been an active debate of varying levels of effectiveness of WBE based on the size of watersheds, catchment type, complexity of sewer systems, and population. Although the science, concepts, and knowledge pertaining to COVID-19 are still evolving and changes rapidly, it is pertinent to check how effective SWEEP can be on the urban scale, that too if cases reported from the given city have been pretty high. Under this scenario, the four major directions in the field of SWEEP may be summarised as i) substantiating the data unravelling the early warning capability of wastewater surveillance for COVID-19 through temporal studies on SARS-CoV-RNA detection; ii) need for the escalation of WBE monitoring of various parts of the globe to generate results from all the levels of COVID-19 situation; iii) developing the model that can use Ct-value obtained through SWEEP into the meaningful predictions for effective COVID-19 pandemic preparedness; and iv) collectively reach to the understanding of critical issues like removal, discharge, decay, dilution, and infectivity due to the presence of SARS-CoV-2 RNA in wastewaters (Kumar et al., 2021).

In view of this, the objective of this study was to put forward the evidence of practical applicability of SWEEP for COVID-19 pandemic management by comparing the detected concentration of SARS-CoV-2 RNA in wastewater of various parts of the city with the COVID- 19 clinical cases. The Idea is that the clinical surveillance hardly classify the city into precise zones where more tests or attention are required, while SWEEP-based information can help zoning of the city and identifying the hotspots on a city scale. The detected concentrations of SARS-CoV-2 RNA in wastewater would reflect the true prevalence of COVID-19 infection in the sewer catchment, including clinically undiagnosed patients, while the number of clinically reported cases covers only diagnosed patients and also depends on the number of PCR diagnosis. We analyzed SARS-CoV-2 RNA in the wastewater samples ( $n=116)$ from nine different locations, including wastewater pumping stations and sewage treatment plant (STP) and in Ahmedabad, India, from September $3^{\text {rd }}$ to November $26^{\text {th }}, 2020$ (thirteen weeks), with the following objectives: a) detection and quantification of SARS-CoV-2-RNA concentration in the influent wastewater samples of Ahmedabad to understand the temporal variation in the pandemic situation over three months, b) weekly resolution of the SARS-CoV-2 RNA data for three months in wastewater samples; and c) explicating the potential of WBE 
medRxiv preprint doi: https://doi.org/10.1101/2021.03.18.21253898; this version posted March 20, 2021. The copyright holder for this preprint (which was not certified by peer review) is the author/funder, who has granted medRxiv a license to display the preprint in perpetuity.

All rights reserved. No reuse allowed without permission.

for COVID-19 surveillance as a potential tool for identifying hotspots and public health monitoring at the city level.

\section{Material and Methods}

\subsection{Sampling approach}

Wastewater samples were collected from nine different locations, including eight wastewater pumping stations and a single sewage treatment plant (Fig. 1). The samples were collected weekly for thirteen weeks from each location during September to November 2020. A total of 116 samples were analyzed in the present study to detect SARS-CoV-2 RNA from nine different sites, comprising 103 samples from eight wastewater pumping stations and 13 samples from a single sewage treatment plant in Ahmedabad, India. All the samples were collected by grab hand sampling using $250 \mathrm{ml}$ sterile bottles (Tarsons, PP Autoclavable, Wide Mouth Bottle, Cat No. 582240, India). Simultaneously, blanks in the same type of bottle were examined to know any contamination during the transport. The samples were kept cool in an ice-box until further process. The analysis was performed on the same day after bringing the samples to the laboratory. All the analyses were performed in Gujarat Biotechnology Research Centre (GBRC), a laboratory approved by the Indian Council of Medical Research (ICMR), New Delhi.

\subsection{Detection and extraction of viral RNA from wastewater samples}

\subsubsection{Precipitation of viral particle}

$30 \mathrm{~mL}$ samples were centrifuged at $4000 \times \mathrm{g}$ (Model: Sorvall ST 40R, Thermo Scientific) for 40 minutes in a $50 \mathrm{~mL}$ falcon tube followed by filtration of supernatant using 0.22 -micron syringe filter (Mixed cellulose esters syringe filter, Himedia). After filtrating $25 \mathrm{~mL}$ of the supernatant, $2 \mathrm{~g}$ of PEG 9000 and $0.437 \mathrm{~g}$ of $\mathrm{NaCl}(17.5 \mathrm{~g} / \mathrm{L})$ were mixed in the filtrate, and this was incubated at $17^{\circ} \mathrm{C}, 100 \mathrm{rpm}$ overnight (Model: Incu-Shaker ${ }^{\mathrm{TM}} 10 \mathrm{LR}$, Benchmark). Next day, the mixture was centrifuged at 14000xg (Model: Kubota 6500, Kubota Corporation) for about 90 minutes. The supernatant was discarded after centrifugation, and the pel- 
medRxiv preprint doi: https://doi.org/10.1101/2021.03.18.21253898; this version posted March 20, 2021. The copyright holder for this preprint (which was not certified by peer review) is the author/funder, who has granted medRxiv a license to display the preprint in perpetuity.

All rights reserved. No reuse allowed without permission.

let was resuspended in $300 \mu \mathrm{L}$ RNase free water. The concentrated sample was kept in $1.5 \mathrm{ml}$ eppendorf at $-40^{\circ} \mathrm{C}$, and this was further used as a sample for RNA isolation.

\subsubsection{RNA isolation, RT-PCR and gene copy estimation}

RNA isolation from the pellet with the concentrated virus was performed using NucleoSpin ${ }^{\circledR}$ RNA Virus isolation kit (Macherey-Nagel GmbH \& Co. KG, Germany). The samples were spiked with MS2 phage as an internal control prior to the RNA extraction provided by TaqPathTM Covid-19 RT-PCR Kit. Some other specifics are, a) the nucleic acid was extracted by NucleoSpin ${ }^{\circledR}$ RNA Virus isolation kit and Qubit 4 Fluorometer (Invitrogen) was used for the total RNA concentrations estimation, b) MS2 phage was taken as a molecular process inhibition control for evaluating the efficiency of nucleic acid extraction and PCR inhibition. (MPC; Haramoto et al., 2018). Briefly, steps were carried out as per the guideline provided with the product manual of Macherey-Nagel GmbH \& Co. KG, and RNAs were detected using real-time PCR (RT-PCR).

Applied Biosystems 7500 Fast Dx Real-Time PCR Instrument (version 2.19 software) was used for SARS-CoV-2 gene detection. In the process, the probes anneal to three specific target sequences located between three unique forward and reverse primers for the $\mathrm{N}$, ORF $1 \mathrm{ab}$, and S genes. A template of $7 \mu \mathrm{l}$ of extracted RNA was used in each reaction with TaqPath $^{\text {TM }} 1$ Step Multiplex Master Mix (Thermofischer Scientific, USA). Total reaction mixture volume of $20 \mu \mathrm{L}$ contained $10.50 \mu \mathrm{L}$ Nuclease-free Water, $6.25 \mu \mathrm{L}$ Master Mix, and 1.25 $\mu L$ COVID-19 Real-Time PCR Assay Multiplex. Three controls were used, namely: positive control (TaqPath ${ }^{\text {TM }}$ COVID 19 Control), one negative control (from extraction run spiked with MS2), and no template control (NTC). The real-time PCR contained 1 incubation step cycle of $25^{\circ} \mathrm{C} \& 2$ minutes, 1 cycle of reverse transcription $53^{\circ} \mathrm{C} \& 10$ minutes, 1 cycle of activation $95^{\circ} \mathrm{C} \& 2$ minutes, and 40 cycles of amplification, including denaturation at $95^{\circ} \mathrm{C}$ for $03 \mathrm{sec}-$ onds and extension $60^{\circ} \mathrm{C}$ for 30 seconds. Finally, results were interpreted using Applied Biosystems Interpretive Software, and Ct values for three target genes i.e., ORF1ab, N Protein, and S Protein of SARS-CoV-2 along with MS2 used as an internal control. 
The samples were considered as positive if at least two of the primer probe sets showed amplification. The average Ct-value of a given sample was then converted to gene copy numbers considering the equivalence of 500 copies of SARS-CoV-2 genes as $26 \mathrm{Ct}$-value (provided with the kit), and the same was extrapolated to derive approximate copies of each gene. The average effective genome concentration present in a given sample was finally calculated by multiplying the RNA amount used as a template with each sample's enrichment factor. Statistical Package for the Social Sciences (SPSS 21) has been used for hypothesis testing through Analysis of variance (ANOVA) and Duncan's Multiple Range Test (DMRT). The OriginPro 2019b data analysis software has been used to draw boxplots.

\section{Results and discussions}

We detected and quantified variation in SARS-CoV-2 RNA from wastewater samples for three months (September and November) to understand the pandemic situation in Ahmedabad, Gujarat, India. Among the 116 samples analyzed in the study, 111 (95.7\%) were found positive, comprising at least two positive RT-PCR results targeting SARS-CoV-2 ORF1ab, S gene, and $\mathrm{N}$ gene assays (Table 1 ). In addition to this, 109/116 (93.7\%) samples showed positive RT-PCR results for each N, ORF $1 \mathrm{~b}$ and $\mathrm{S}$ genes. The distribution analysis of $\mathrm{Ct}$ values for different genes using boxplot is represented in Fig.2. The average Ct values for N, ORF $1 \mathrm{ab}$, and S genes were 32.50, 32.36, and 33.85, respectively. The average Ct values of internal control (MS2 bacteriophage) was 28.2, and no SARS-CoV-2 genes were detected in the negative control samples.

\subsection{Monthly and Weekly Variations}

Monthly variation depicted a significant decline of $89.7,63.7$, and $90.1 \%$ in N, ORF-1ab, and $S$ gene concentration (copies/L), respectively in October compared to September 2020, followed by a sharp increment in November 2020 i.e. $~ 25$ folds in $\mathrm{N}$ gene, $\sim 22$ folds in ORF 1ab and $\sim 26$ folds in S gene. The PCR products for all three genes were maximum in wastewater samples of November, followed by September and October (Fig. 3 a-c). Likewise, the ge- 
medRxiv preprint doi: https://doi.org/10.1101/2021.03.18.21253898; this version posted March 20, 2021. The copyright holder for this preprint (which was not certified by peer review) is the author/funder, who has granted medRxiv a license to display the preprint in perpetuity.

All rights reserved. No reuse allowed without permission.

nome concentration of SARS-CoV-2 RNA was maximum in the month of November ( 10729 copies/ L), followed by September ( 3047 copies/ L), and October (454 copies/ L) in line with $a \sim 1.5$-fold rise in the number of confirmed cases during the study period ( $3^{\text {rd }}$ September 2020 and $26^{\text {th }}$ November 2020) (Fig. 3d). Trends of monthly variation in SARS-CoV-2 RNA concentration in the wastewater samples may be ascribed to a decline of $19.3 \%$ in active cases in October 2020 and a rise of $1.82 \%$ in November 2020 compared to the preceding months. A little percentage increase of $1.82 \%$ in the active cases equaled 59 cases, while the total number of active cases was 3293 in the month of November 2020. However, at the same time, a prominent rise of $17.3 \%$ (i.e. 7386 new cases) noticed in November 2020. Also, a monthly decrease of $3.73 \%$ in recovered cases was noticed in November compared to October 2020 . The monthly recovery rate of patients was $16.61,19.31$, and $15.58 \%$ in September, October, and November 2020, respectively. Apart from that, people's casual and reluctant attitude during the festive season in India (mid-October to mid-Nov) might be the reason for the piercing rise in COVID-19 cases.

Weekly temporal variations in average SARS-CoV-2 gene copies were analyzed for SARSCoV-2 RNA presence in samples collected from all the sampling locations in Ahmedabad and are displayed in Fig. 4a-d. One-way ANOVA and Duncan post hoc test $(\mathbf{p}<\mathbf{0 . 0 5})$ were performed to see the significance level in gene copy variation among different sampling dates. The results showed significant differences in all three gene copies, i.e. N-gene (ANOVA, $F=$ 7.49, $p<0.001$ ), ORF-1ab genes (ANOVA, $F=5.94, p<0.001$ ), and S-gene (ANOVA, $F=8.25, p$ $<0.001$ ) on the temporal scale (sampling dates). Similarly, differences were significant in the case of genome concentration (ANOVA, $F=7.12, \mathrm{p}<0.001$ ). All three gene copies (i.e. $\mathrm{N}$, ORF1ab, and S genes) and genome concentration were detected maximum on November 19 th, 2020 , and values were significant $(p<0.05)$ as compared to other sampling dates. The exponential rise in virus geneconcentration might be due to the decline in the decreasing trend $\left(<-0.1 \%\right.$, November $\left.12^{\text {th }}, 2020\right)$ followed by the increase in the number of active cases (i.e., $2.5 \%$ which corresponded to the 82 new cases on November $19^{\text {th }}, 2020$ ), compared to the earlier sampling dates. 
medRxiv preprint doi: https://doi.org/10.1101/2021.03.18.21253898; this version posted March 20, 2021. The copyright holder for this preprint (which was not certified by peer review) is the author/funder, who has granted medRxiv a license to display the preprint in perpetuity.

All rights reserved. No reuse allowed without permission.

\subsection{SWEEP-based city zonation and Identification of Hot-Spots}

The SWEEP technology offers a better picture of the pandemic situation at the sub-city or zone level, relying on the SARS-CoV-2 RNA concentration in wastewater samples of a particular area. SWEEP data can help to estimate the actual extent of the infection due to the SARS-CoV-2, as it covers both asymptomatic and presymptomatic patients, which may be underestimated by clinical surveillance. Therefore, it would help in SWEEP data-based zonation of the city, and identifying hot-spots, which require more attention and rapid testing. On the other hand, clinical surveillance usually fails to classify the city into distinct zones based on the severity of the pandemic situation as it entirely depends on the data provided by the clinical centres that facilitate patients from the entire city, and dedicated manpower is required to maintain the demographic data. Also, sometimes-clinical survey-based secondary data is unreliable because it doesn't include asymptomatic patients, presymptomatic patients, and patients who don't go through clinical tests.

Depending on the genome concentration in wastewater samples based on analytical results, we identified highly susceptible areas for COVD-19 infection and its transmission among the community. The north (Motera and Ranip) and east (Odhav and Satyam) zones were highly affected areas with an average genome concentration of $\sim 15,574$ and $\sim 13,397$ copies/L, respectively, in November (Fig. 5a). Likewise, in September, wastewater samples collected from the east zone showed maximum genome concentration ( $\sim 734$ copies/ L), followed by the north zone ( $\sim 3536$ copies/ L). Though areas present in north and east zones showed high virus genetic load, yet a sharp rise in SARS-CoV-2 RNA was noticed in all the zones in November 2020 (Fig. 5a). It has also been represented in a summarised format with comparison to the affected population in the city (Fig.5b \& c). Overall, proper scrutiny and regular monitoring of wastewater could be useful for preparedness against adverse conditions as appeared in post-festive days in Ahmedabad.

There are some studies available around the globe on early detection of SARS-CoV-2 RNA in wastewater, even before the first report of clinical diagnosis. For example, Madema et al. (2020) reported the presence of SARS-CoV-2 genetic material in wastewater in February, 
even before the official declaration of the first case in the Netherlands. Likewise, La Rosa et al. (2020) reported SARS-CoV-2 genetic material in wastewater samples before the first official documented report from two different cities in Italy. Similarly, Randazzo et al. (2020) detected SARS-CoV-2 RNA in wastewater samples from Spain. Since then, many researchers detected and reported the occurrence of SARS-CoV-2 RNA in wastewater samples and pondered its applicability for WBE surveillance (Ahmed et al., 2020, Kumar et al. 2020 a,c). However, a few studies available focused on assessing its potential on the temporal scale in relation to the changes in COVID cases.

\subsection{Early Warning Potential of WBE}

In this view, the present research work followed our first proof concept study, where we detected SARS-CoV-2 genetic material in wastewater and proposed its wide applicability for COVID surveillance in the community (Kumar et al. 2020a). Examining the potential of WBE for COVID-19 surveillance as a potential tool showed that the percentage change in genome concentration level on a particular date was in conjunction with the confirmed cases registered 1-2 weeks later on a temporal scale by the regulatory authority based on clinical tests (Fig. 6). For example, on October, $8^{\text {th }}, 2020$, a sharp decline of $\sim 86 \%$ was noticed in the percentage change in the average genome concentration which was followed by $\sim 0.4 \%$ decline in the percentage change in confirmed COVID cases on October, $22^{\text {nd }}, 2020$. Likewise, on November $5^{\text {th }}, 2020$, a steep hike of $>22$-folds in the percentage change in the average genome concentration was noticed compared to the earlier sampling date, which was followed by $\sim 0.6 \%$ and $2.37 \%$ increment in the percentage change in confirmed COVID cases on November $19^{\text {th }}$ and November, $26^{\text {th }}, 2020$, respectively. Therefore, we can predict the severity of the pandemic situation 1-2 weeks prior to the official reports by the regulatory body based on clinical tests.

The results unravel the potential of WBE surveillance of COVID-19 as an early warning tool displayed by the adequate presence of SARS-CoV-2 genetic material in wastewater samples though limited cases were documented and based on the immediate future trends. These findings were in agreement with those of Ahmed et al. (2020b), who noticed a longitudinal 
decline in the presence of SARS-CoV-2 RNA with the tapering of the first epidemic wave; however, there was no concrete relationship between virus RNA and daily cases numbers.

\subsection{Environmental Perspectives}

Wastewater based epidemiology (WBE) has been proved highly effective in the early warning of COVID-19, however owing to its newness, there remains several aspects to be explored through continuous monitoring. The future work may focus on: i) To monitor the COVID-19 curve in the post-vaccination period through quantifying the genetic material of SARS-CoV-2 in the wastewaters of a given city (Ahmedabad); ii) To understand the association of antibiotic resistance with COVID-19 prevalence; iii) To develop an online portal with weekly update of genome concentration with accessibility provided to the public and policy makers; iii) To estimate the potential risk of SARS-CoV-2 in natural water bodies through various water activities using a quantitative microbial risk assessment (QMRA) framework; iv) To have a longer valuable time-series data to check the robustness of early warning capability of the techniques, and its possible benefits of making it accessible for public; and v) To develop predictive modelling to connect the missing points and for the advancement of SWEEP and support to other surveillance protocols.

Longer time-series data of SWEEP can be used for various modelling and risk evaluation study. It can also provide an additional way to understand the efficacy of vaccine through high resolution signs indicative of temporal variation in SARS-CoV-2 RNA. SWEEP can be taken into account for developing advisory in the context of rapid-testing, number of testing, community clearance, hotspot identification, vaccine need identification zones as well as, to stay at home the accurate scale of the pandemic must use the environmental surveillances of SARS-CoV-2 in wastewater to supplement the individual testing and timely identification.

In the first phase, we have explicitly shown the capability of WBE as early warning and city zonation tool. However, in a country like India, where sewer systems are not complete and 
medRxiv preprint doi: https://doi.org/10.1101/2021.03.18.21253898; this version posted March 20, 2021. The copyright holder for this preprint (which was not certified by peer review) is the author/funder, who has granted medRxiv a license to display the preprint in perpetuity.

All rights reserved. No reuse allowed without permission.

treatment systems are not well-managed, it is important to have long-term monitoring for a year at the least so that precious meaningful data for the developing country can be obtained. Furthermore, a practical guide and pandemic management tools can be developed by integrating the virtues of information technology with early warning capability of wastewater surveillance. A confidence may be generated by inculcating informed understanding among the commons about the effectiveness of treatment plants through environmental surveillance of COVID-19, detecting the genetic material of SARS-CoV-2 in sewage. So that the government agencies like AMC can be convinced to incorporate WBE for any COVID-like epidemic/pandemic outbreak in the future.

\section{Conclusion}

A temporal variation of SARS-CoV-2 RNA presence in wastewater was studied for a period of three months in Ahmedabad, India. A total of 111 samples (95.7\%) of the total 116 samples tested in the study were found to be positive, with at least two positive RT-PCR results targeting SARS-CoV-2 ORF1ab, S gene, and N gene assays. Monthly variation depicted a significant decline in all three gene copies in October compared to September 2020, followed by a sharp increment in November 2020. Correspondingly, the descending order of average genome concentration was November ( 10729 copies/ L) > September ( 3046 copies/ L) > October ( $\sim 53$ copies/ L). This finding was further supported by the relation between the percentage change in genome concentration level and confirmed cases, which followed a similar trend on the temporal scale with a $\sim 1$ to 2 week's time distance. Also, the genome concentrations at various sampling locations were well correlated with the number of cases in a particular zone. The results unveiled the untapped potential of WBE surveillance of COVID19 as an early warning tool for practical use of city zonation based on SWEEP data for actual scenarios and future prediction. This approach may help the authorities identify the hotspots within a city and tuning effective management interventions. Further research may be focused on quantifying the correlation of SWEEP results with clinical surveillance data and developing a predictive model that can translate SWEEP data for easy propagation to policymakers and the general public to enhance the preparedness and management of pandemics. 
Notes:

The authors declare no competing financial interest.

\section{Acknowledgement:}

This work is funded by UNICEF, Gujarat and UKIERI. We also acknowledge the help received from Dr. Arbind $\mathrm{K}$ Patel, Mr. Alok Thakur, and other GBRC staffs who contributed towards sample and data analyses.

\section{References}

Ahmed, W., Tscharke, B., Bertsch, P.M., Bibby, K., Bivins, A., Choi, P., Clarke, L., Dwyer, J., Edson, J., Nguyen, T.M.H. and O'Brien, J.W., 2020. SARS-CoV-2 RNA monitoring in wastewater as an early warning system for COVID-19 transmission in the community: a temporal case study. Science of The Total Environment, p.144216. https://doi.org/10.1016/j.scitotenv.2020.144216

Chan, P.K., Lui, G., Hachim, A., Ko, R.L., Boon, S.S., Li, T., Kavian, N., Luk, F., Chen, Z., Yau, E.M. and Chan, K.H., 2020. Serologic responses in healthy adult with SARS-CoV-2 reinfection, Hong Kong, August 2020. Emerging infectious diseases, 26(12), p.3076. doi: 10.3201/eid2612.203833

Cheung, K.S., Hung, I.F., Chan, P.P., Lung, K.C., Tso, E., Liu, R., Ng, Y.Y., Chu, M.Y., Chung, T.W., Tam, A.R. and Yip, C.C., 2020. Gastrointestinal manifestations of SARS-CoV-2 infection and virus load in fecal samples from the Hong Kong cohort and systematic review and metaanalysis. Gastroenterology. https://doi.org/10.1053/j.gastro.2020.03.065

Gupta, M.K., Vemula, S., Donde, R., Gouda, G., Behera, L. and Vadde, R., 2020. In-silico approaches to detect inhibitors of the human severe acute respiratory syndrome coronavirus envelope protein ion channel.Journal of Biomolecular Structure and Dynamics, pp.1-11. https://doi.org/10.1080/07391102.2020.1751300

Haramoto, E., Malla, B., Thakali, O., Kitajima, M., 2020. First environmental surveillance for the presence of SARS-CoV-2 RNA in wastewater and river water in Japan. Science of The Total Environment, 737, 140405. https://doi.org/10.1016/j.scitotenv.2020.140405

Hata, A., Hara-Yamamura, H., Meuchi, Y., Imai, S. and Honda, R., 2020. Detection of SARS-CoV-2 in wastewater in Japan during a COVID-19 outbreak. Science of The Total Environment, p.143578. https://doi.org/10.1016/j.scitotenv.2020.143578

Havers, F.P., Reed, C., Lim, T., Montgomery, J.M., Klena, J.D., Hall, A.J., Fry, A.M., Cannon, D.L., Chiang, C.F., Gibbons, A. and Krapiunaya, I., 2020. Seroprevalence of antibodies to SARS-CoV-2 in 10 sites in the United States, March 23-May 12, 2020. JAMA, 180(12), pp.1576-1586. doi:10.1001/jamainternmed.2020.4130

Kumar, M., Patel, A.K., Shah, A.V., Raval, J., Rajpara, N., Joshi, M. and Joshi, C.G., 2020a. First proof of the capability of wastewater surveillance for COVID-19 in India through detection of genetic material of SARS-CoV-2. Science of The Total Environment, 746, p.141326. https://doi.org/10.1016/i.scitotenv.2020.141326

Kumar, M., Thakur, A.K., Mazumder, P., Kuroda, K., Mohapatra, S., Rinklebe, J., Ramanathan, A.L., Cetecioglu, Z., Jain, S., Tyagi, V.K. and Gikas, P., 2020b. Frontier review on the propensity and repercussion of SARS-CoV-2 migration to aquatic environment. Journal of Hazardous Materials Letters, 1, p.100001. https://doi.org/10.1016/j.hazl.2020.100001 
Kumar, M., Taki, K., Gahlot, R., Sharma, A. and Dhangar, K., 2020c. A chronicle of SARS-CoV-2: Part-IEpidemiology, diagnosis, prognosis, transmission and treatment. Science of The Total Environment, p.139278.

Kumar, M., Kuroda, K., Patel, A.K., Patel, N., Bhattacharya, P., Joshi, M. and Joshi, C.G., 2020d. Decay of SARS-CoV-2 RNA along the wastewater treatment outfitted with Upflow Anaerobic Sludge Blanket (UASB) system evaluated through two sample concentration techniques. Science of the Total Environment, 754, p.142329. https://doi.org/10.1016/j.scitotenv.2020.142329

Kumar, M., Alamin, M., Kuroda, K., Dhangar, K., Hata, A., Yamaguchi, H., \& Honda, R. (2021). Potential discharge, attenuation and exposure risk of SARS-CoV-2 in natural water bodies receiving treated wastewater. npj Clean Water, 4(1), 1-11. https://doi.org/10.1038/s41545-021-00098-2

La Rosa, G., laconelli, M., Mancini, P., Ferraro, G.B., Veneri, C., Bonadonna, L., Lucentini, L. and Suffredini, E., 2020. First detection of SARS-CoV-2 in untreated wastewaters in Italy. Science of The Total Environment, p.139652. https://doi.org/10.1016/j.scitotenv.2020.139652

Lavezzo, E., Franchin, E., Ciavarella, C., Cuomo-Dannenburg, G., Barzon, L., Del Vecchio, C., Rossi, L., Manganelli, R., Loregian, A., Navarin, N. and Abate, D., 2020. Suppression of a SARS-CoV-2 outbreak in the Italian municipality of Vo'. Nature, 584(7821), pp.425-429. https://doi.org/10.1038/s41586$\underline{020-2488-1}$

Medema, G., Heijnen, L., Elsinga, G., Italiaander, R., Brouwer, A., 2020. Presence of SARS Coronavirus-2 RNA in sewage and correlation with reported COVID-19 prevalence in the early stage of the epidemic in the Netherlands. Environ Sci Technol Lett. 7 (7), 511-516. https://doi.org/10.1021/acs.estlett.0c00357

Mizumoto, K. and Chowell, G., 2020. Estimating Risk for Death from Coronavirus Disease, China, JanuaryFebruary 2020. Emerging infectious diseases, 26(6), p.1251. doi: 10.3201/eid2606.200233

Ni, W., Yang, X., Yang, D., Bao, J., Li, R., Xiao, Y., Hou, C., Wang, H., Liu, J., Yang, D. and Xu, Y., 2020. Role of angiotensin-converting enzyme 2 (ACE2) in COVID-19. Critical Care, 24(1), pp.1-10. https://doi.org/10.1186/s13054-020-03120-0

Nishiura, H., Linton, N.M. and Akhmetzhanov, A.R., 2020. Serial interval of novel coronavirus (COVID-19) infections. International journal of infectious diseases. https://doi.org/10.1016/j.ijid.2020.02.060

Prevost, B., Lucas, F. S., Goncalves, A., Richard, F., Moulin, L., Wurtzer, S., 2015. Large scale survey of enteric viruses in river and waste water underlines the health status of the local population. Environment international, 79, 42-50. https://doi.org/10.1016/i.envint.2015.03.004

Randazzo,W., Truchado, P., Cuevas-Ferrando, E., Simón, P., Allende, A., Sánchez, G., 2020a. SARS-CoV-2 RNA in wastewater anticipated COVID-19 occurrence in a Low prevalence area. Water Res. 181, 115942. https://doi.org/10.1016/j.watres.2020.115942

Rimoldi, S. G., Stefani, F., Gigantiello, A., Polesello, S., Comandatore, F., Mileto, D., Maresca, M., Longobardi, C., Mancon, A., Romeri, F., Pagani, C., Moja, L., Gismondo, M.R., Salerno, F.,2020. Presence and vitality of SARS-CoV-2 virus in wastewaters and rivers. Science of the Total Environment, 744:140911

Tiwari, S. B., Gahlot, P., Tyagi, V. K., Zhang, L., Zhou, Y., Kazmi, A. A., Kumar, M., 2021. Surveillance of Wastewater for Early Epidemic Prediction (SWEEP): Environmental and health security perspectives in the post COVID-19 Anthropocene. Environmental Research, 110831. https://doi.org/10.1016/i.envres.2021.110831

Tran, H. N., Le, G. T., Nguyen, D. T., Juang, R. S., Rinklebe, J., Bhatnagar, A., Lima, E.C., Iqbal, H. M. N., Sarmah, A. K., Chao, H. P., 2020. SARS-CoV-2 coronavirus in water and wastewater: A critical review about presence and concern. Environmental Research, 110265. https://doi.org/10.1016/i.envres.2020.110265 
medRxiv preprint doi: https://doi.org/10.1101/2021.03.18.21253898; this version posted March 20, 2021. The copyright holder for this preprint (which was not certified by peer review) is the author/funder, who has granted medRxiv a license to display the preprint in perpetuity. All rights reserved. No reuse allowed without permission.

Wurtzer, S., Marechal, V., Mouchel, J.M., Maday, Y., Teyssou, R., Richard, E., Almayrac, J.L. and Moulin, L., 2020. Evaluation of lockdown impact on SARS-CoV-2 dynamics through viral genome quantification in Paris wastewaters. medRxiv. https://doi.org/10.1101/2020.04.12.20062679

Wong, M.C., Huang, J., Lai, C., Ng, R., Chan, F.K. and Chan, P.K., 2020. Detection of SARS-CoV-2 RNA in fecal specimens of patients with confirmed COVID-19: a meta-analysis. Journal of Infection. https://doi.org/10.1016/i.jinf.2020.06.012

World Health Organization Novel Coronavirus (2019-nCoV) Situation Report - 1 (2020) https://www.who.int/emergencies/diseases/novel-coronavirus-2019/situation432-reports

Xiao, F., Tang, M., Zheng, X., Liu, Y., Li, X. and Shan, H., 2020. Evidence for gastrointestinal infection of SARS-CoV-2. Gastroenterology, 158(6), https://doi.org/10.1053/j.gastro.2020.02.055

pp.1831-1833.

Yang, R., Gui, X. and Xiong, Y., 2020. Comparison of clinical characteristics of patients with asymptomatic vs symptomatic coronavirus disease 2019 in Wuhan, China. JAMA Network Open, 3(5), pp.e2010182-e2010182. doi:10.1001/jamanetworkopen.2020.10182

Zhang, N., Gong, Y., Meng, F., Bi, Y., Yang, P. and Wang, F., 2020. Virus shedding patterns in nasopharyngeal and fecal specimens of COVID-19 patients. MedRxiv. https://doi.org/10.1101/2020.03.28.20043059

Zhu, Y., Oishi, W., Maruo, C., Saito, M., Chen, R., Kitajima, M., \& Sano, D., 2021. Early warning of COVID19 via wastewater-based epidemiology: potential and bottlenecks. Science of the Total Environment, 145124. https://doi.org/10.1016/i.scitotenv.2021.145124 

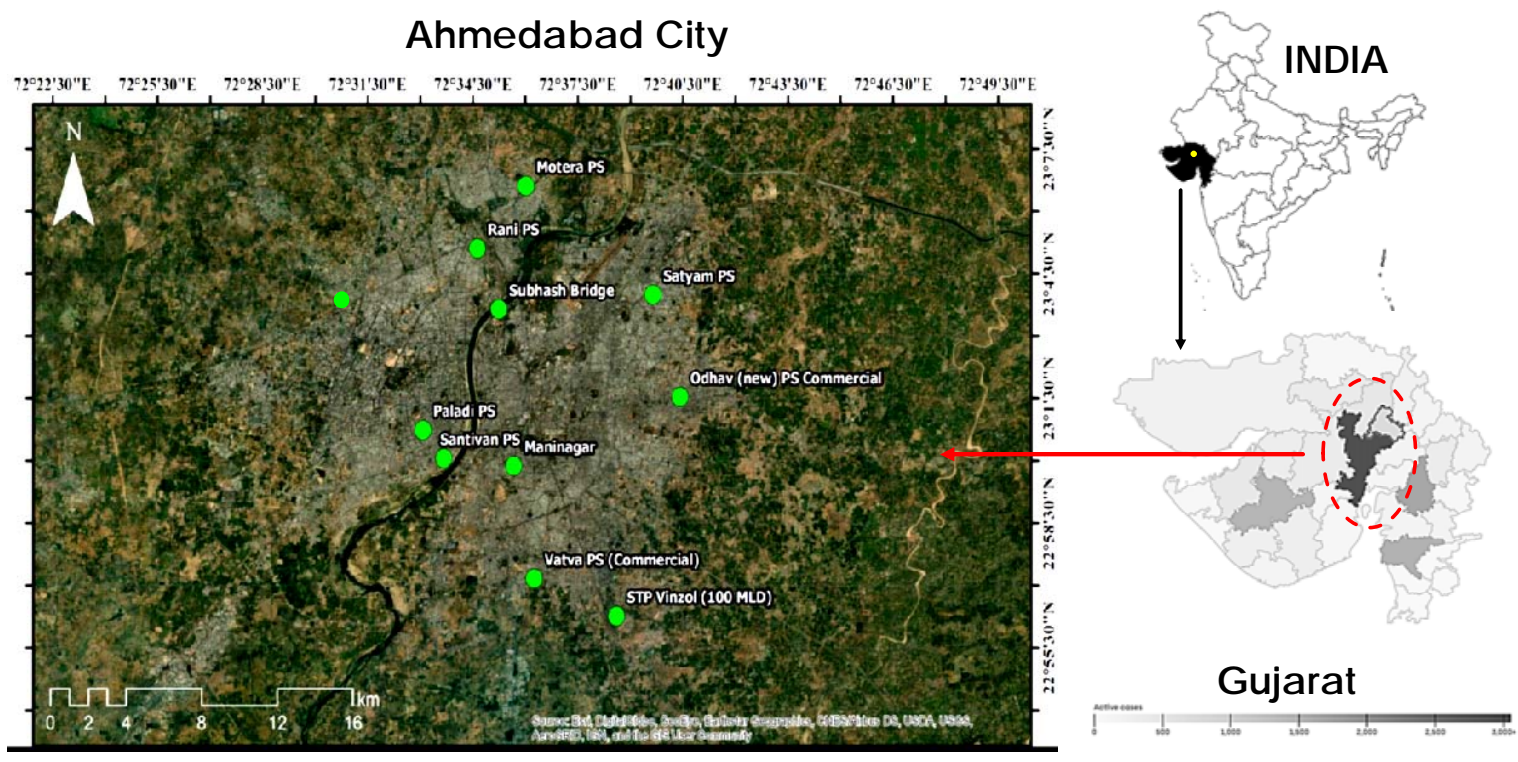

Fig. 1 Geospatial position of sampling locations in Ahmedabad city
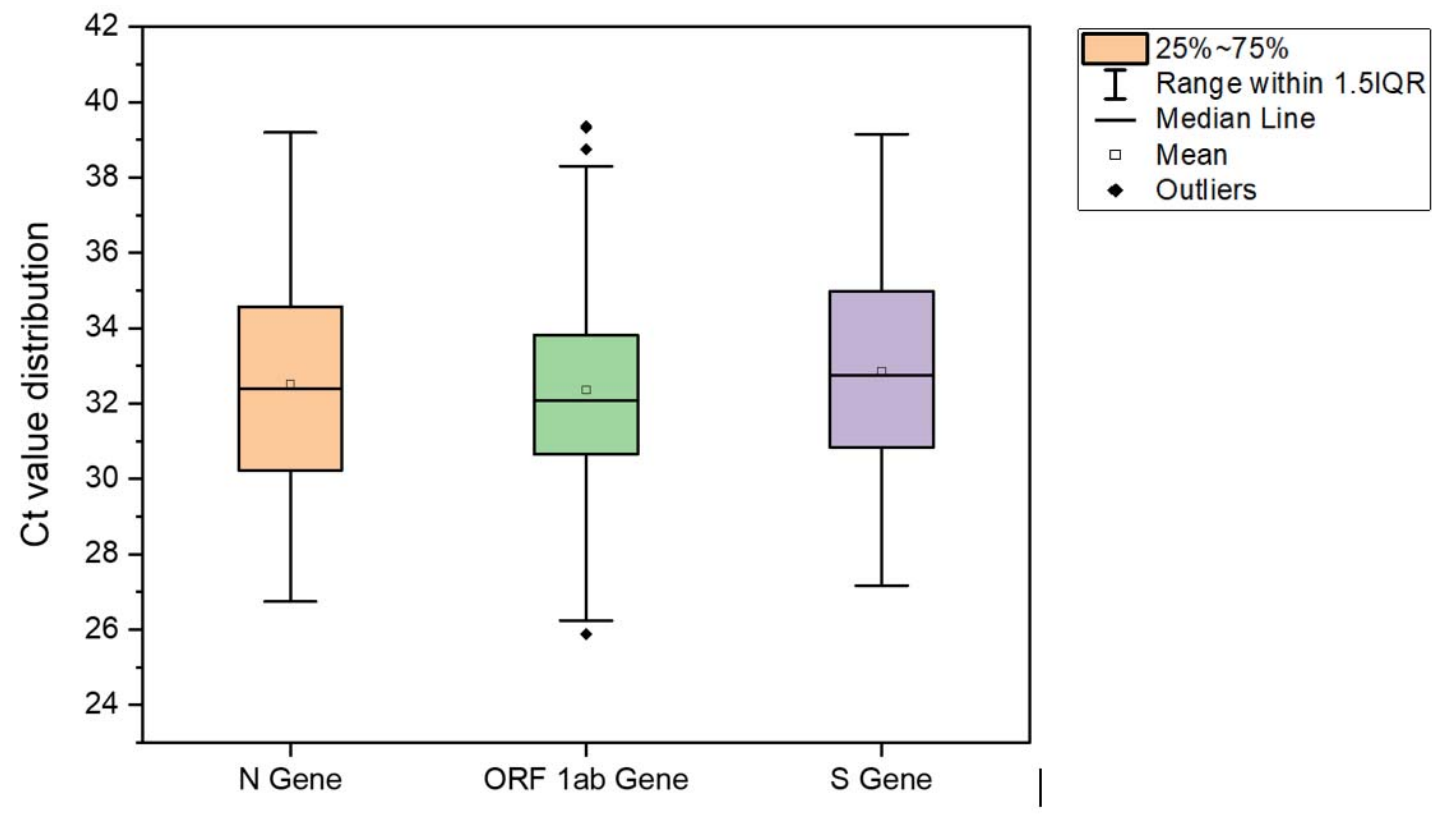

Fig. 2 Distribution of $\mathrm{Ct}$ values of SARS-CoV-2 genes during the study period. 
medRxiv preprint doi: https://doi.org/10.1101/2021.03.18.21253898; this version posted March 20, 2021. The copyright holder for this preprint (which was not certified by peer review) is the author/funder, who has granted medRxiv a license to display the preprint in perpetuity. All rights reserved. No reuse allowed without permission.
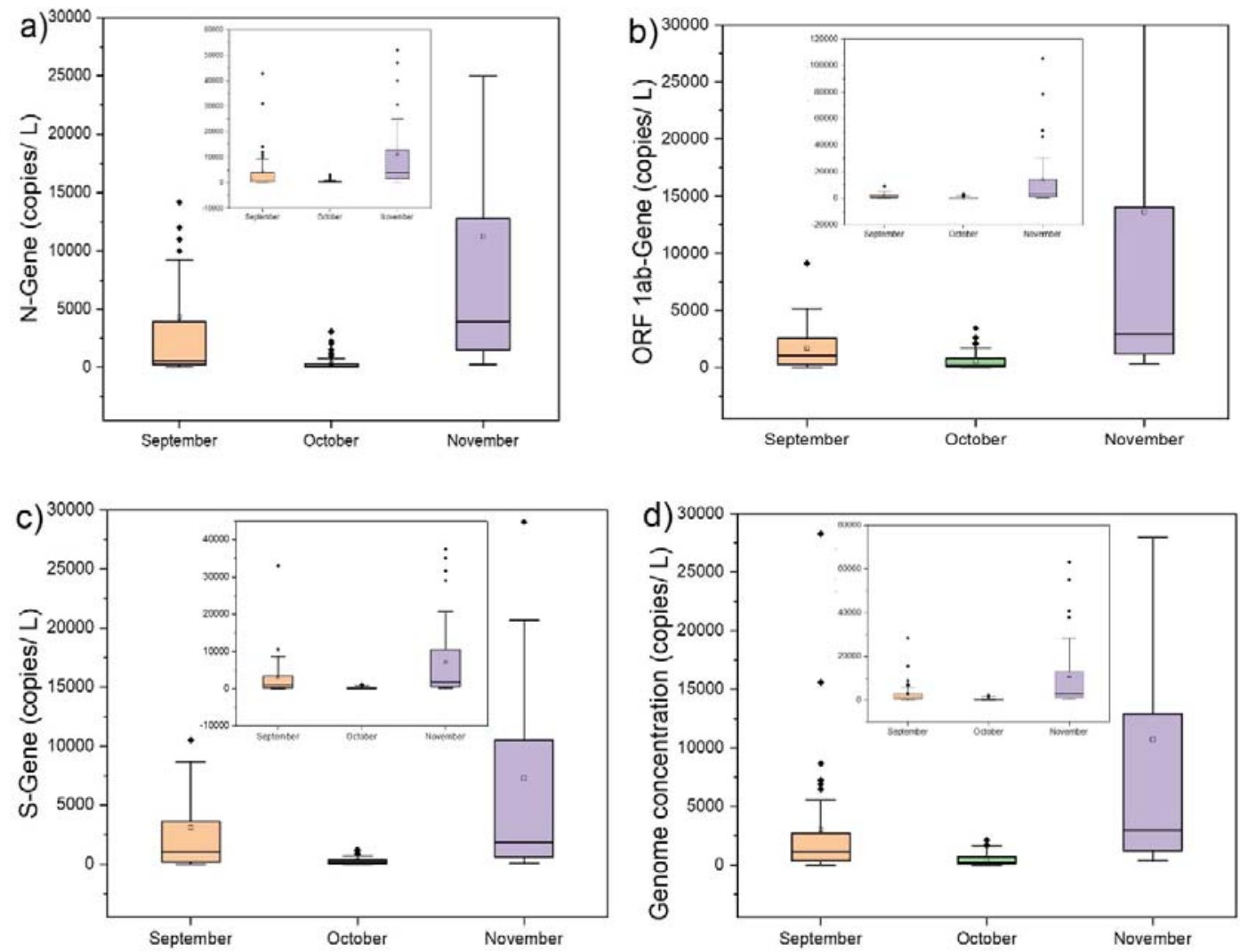

Fig. 3 Distribution of SARS-CoV-2 gene copies on a temporal scale (monthly variation). 

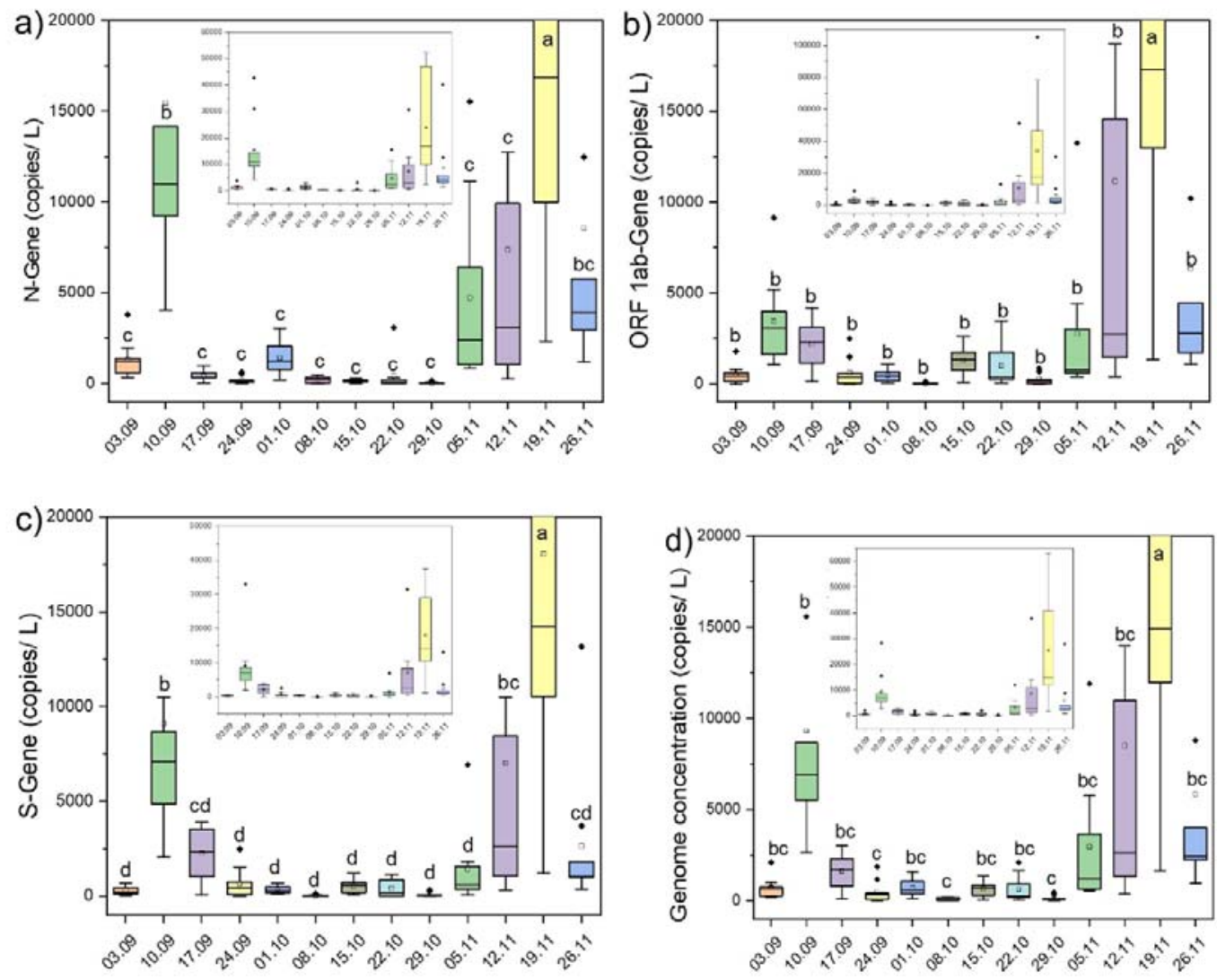

Fig. 4 Temporal variations in targeted gene copies of SARS-CoV-2, collected from different sampling points a.) $\mathrm{N}$ gene, b.) ORF $1 \mathrm{ab}$ gene, c.) $\mathrm{S}$ gene, and d) Genome concentration 
a)

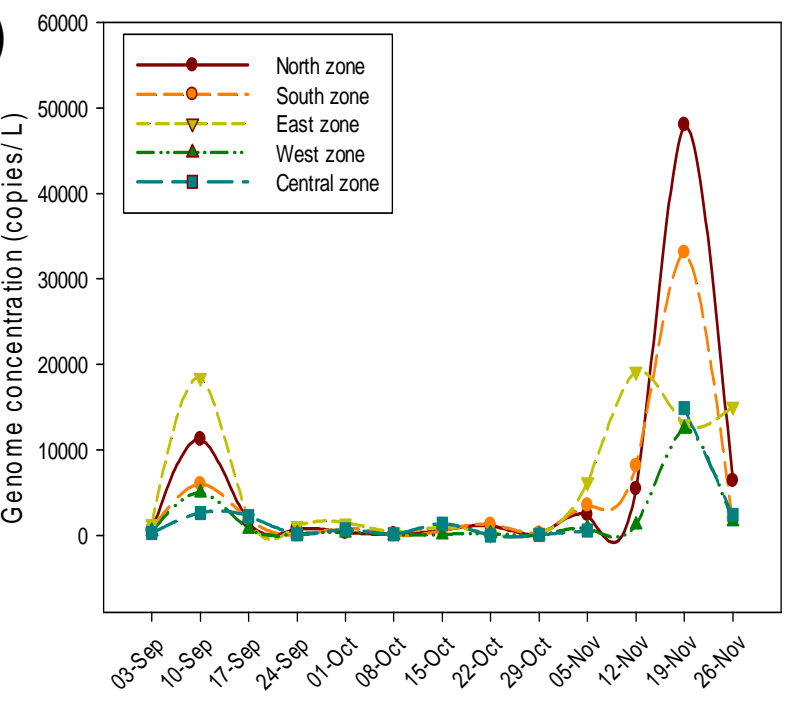

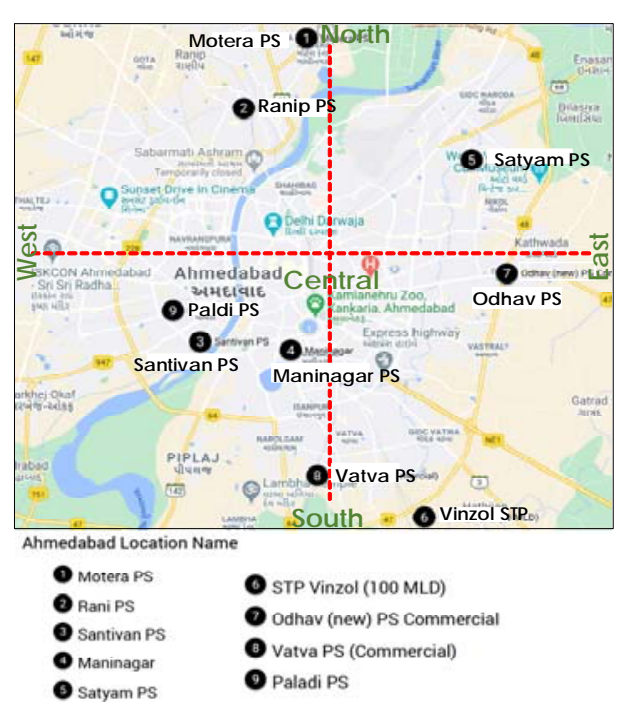

c)

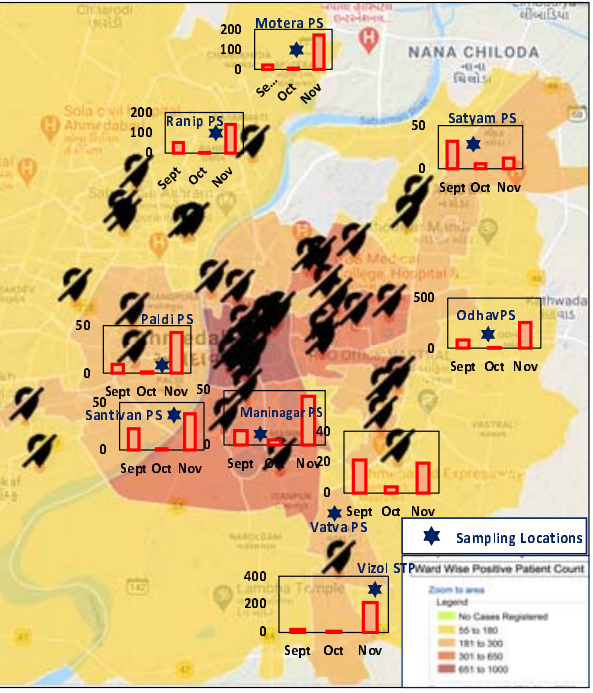

Fig. 5. a) Zone-wise Covid-19 pandemic status in Ahmedabad city; b) Heat map of the overall infected population in Ahmedabad City obtained from http://google.org/crisismap/a/gmail.com/amdcovid19; c) Monthwise Effective genome concentration at the sampling locations (the present study) overlaying at wardwise positive patient count (http://google.org/crisismap/a/gmail.com/amdcovid19). 


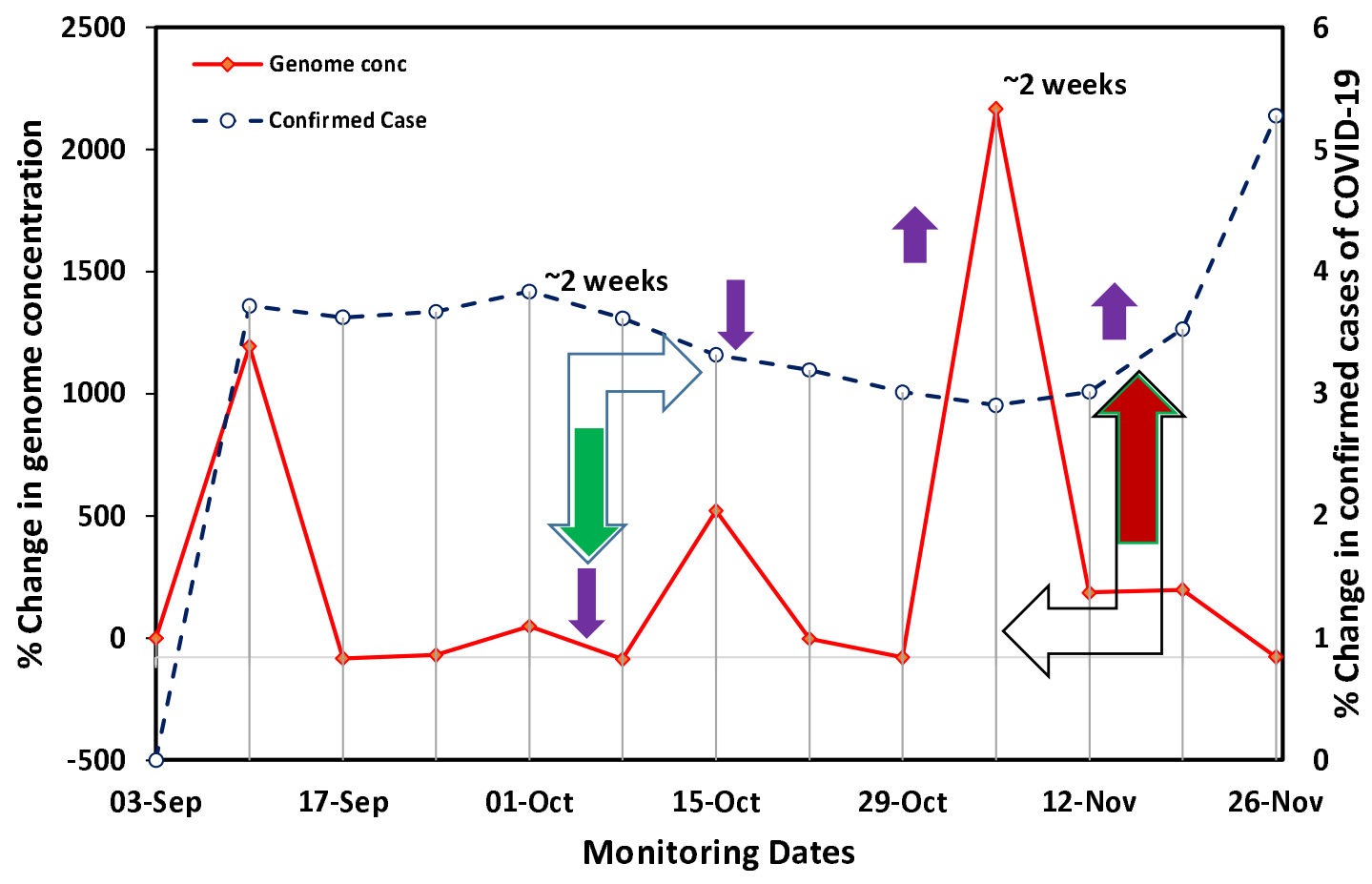

Fig. 6 Potential and evidence of wastewater based epidemiology surveillance of Covid-19 pandemic as an early warning tool. 
Table 1. Temporal variation in gene copies of the SARS-CoV-2 targeted genes and genome concentration at various locations in Ahmedabad city

\begin{tabular}{|c|c|c|c|c|c|c|c|c|c|c|c|c|c|c|}
\hline \multirow{5}{*}{ के } & \multirow{2}{*}{$\begin{array}{c}\text { Sampling } \\
\text { date }\end{array}$} & \multicolumn{4}{|c|}{ September, 2020} & \multicolumn{5}{|c|}{ October, 2020} & \multicolumn{4}{|c|}{ November, 2020} \\
\hline & & 3.09 & 10.09 & 17.09 & 24.09 & 0.1 .10 & 8.10 & 15.10 & 22.10 & 29.10 & 5.11 & 12.11 & 19.11 & 26.11 \\
\hline & $\begin{array}{l}\text { Active } \\
\text { Cases }\end{array}$ & 3671 & 4168 & 4038 & 4252 & 4122 & 3614 & 3472 & 3451 & 3372 & 3283 & 3280 & 3362 & 3293 \\
\hline & $\begin{array}{c}\text { Confirmed } \\
\text { cases }\end{array}$ & 32013 & 33204 & 34408 & 35672 & 37041 & 38381 & 39655 & 40922 & 42155 & 43381 & 44690 & 46268 & 48710 \\
\hline & $\begin{array}{c}\text { SARS-CoV-2 } \\
\text { Genes }\end{array}$ & \multicolumn{13}{|c|}{ Gene Copies (copies/ L) x $10^{2}$} \\
\hline \multirow{4}{*}{ 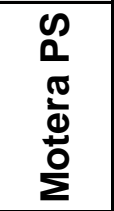 } & $\mathrm{N}$ & 19.9 & 120 & 0.36 & 1.56 & 7.99 & 2.84 & 1.23 & 30.8 & ND & 28.7 & 70.8 & 522.7 & 57.8 \\
\hline & ORF & 5.84 & 16 & 1.43 & 5.73 & 1.7 & 1.16 & 10 & 20.8 & ND & 3.86 & 104 & 783.2 & 44.4 \\
\hline & $S$ & 4.4 & 71.1 & 0.78 & 4.6 & 1.27 & 1.32 & 3.17 & 11.3 & 0.34 & 3.65 & 63.9 & 350.8 & 18.2 \\
\hline & Genome & 10.1 & 69.1 & 0.86 & 3.96 & 3.65 & 1.77 & 4.8 & 21 & ND & 12.1 & 79.5 & 552.2 & 40.1 \\
\hline \multirow{4}{*}{ 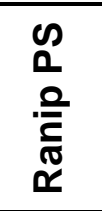 } & $\mathrm{N}$ & 3.18 & 310.4 & 9.8 & 5.4 & 6.61 & 3.73 & 2.17 & 0.68 & 0.17 & 64.2 & 33.1 & 471 & 124.7 \\
\hline & ORF & ND & 51.9 & 41.7 & 14.8 & 0.86 & ND & 13.3 & 3.59 & 0.95 & 29.9 & 30.5 & 463.2 & 101.9 \\
\hline & $S$ & 0.46 & 105 & 39.2 & 15.2 & 1.67 & 0.51 & 5.91 & 0.18 & 0.78 & 15.8 & 24.8 & 289.9 & 37.04 \\
\hline & Genome & 1.22 & 155.8 & 30.2 & 11.8 & 3.05 & 1.41 & 7.14 & 1.48 & 0.63 & 36.6 & 29.4 & 408.1 & 87.9 \\
\hline \multirow{4}{*}{$\begin{array}{l}\infty \\
\frac{0}{\pi} \\
\frac{0}{\pi} \\
0\end{array}$} & $\mathrm{~N}$ & 5 & 40.5 & 3.26 & ND & 12.1 & 0.27 & 0.23 & 0.55 & 0.3 & 8.69 & 12.6 & 99.8 & 39.1 \\
\hline & ORF & 1.73 & 11.7 & 11.1 & 0.28 & 3.31 & 0.19 & 0.69 & 2.17 & 0.27 & 5.77 & 24.4 & 140.5 & 21.9 \\
\hline & $S$ & 0.79 & 29.6 & 9.8 & 0.75 & 1.76 & ND & 0.66 & 2.78 & 0.69 & 3.52 & 27.2 & 118.9 & 9.93 \\
\hline & Genome & 2.51 & 27.2 & 8.07 & 0.34 & 5.74 & 0.15 & 0.53 & 1.83 & 0.42 & 5.99 & 21.4 & 119.7 & 23.6 \\
\hline \multirow{3}{*}{ 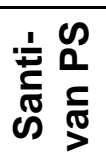 } & $\mathrm{N}$ & 12.4 & 100 & 3.07 & 1.37 & 2.15 & 2.37 & 0.87 & 0.96 & ND & 15.1 & 2.74 & 116.3 & 12 \\
\hline & ORF & 4 & 30.4 & 9.74 & 4.13 & 0.65 & 0.24 & 3.9 & 5.17 & ND & 12.2 & 3.89 & 129.6 & 12.9 \\
\hline & $S$ & 3.14 & 86.6 & 10.4 & 4.57 & 1.2 & ND & 1.87 & 1.55 & 0.15 & 6.03 & 4.24 & 141.9 & 3.67 \\
\hline
\end{tabular}




\begin{tabular}{|c|c|c|c|c|c|c|c|c|c|c|c|c|c|c|}
\hline & Genome & 6.51 & 72.3 & 7.74 & 3.36 & 1.33 & 0.87 & 2.21 & 2.56 & ND & 11.1 & 3.63 & 129.3 & 9.5 \\
\hline \multirow{4}{*}{ 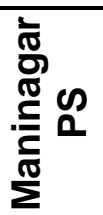 } & $\mathrm{N}$ & 5.8 & 48.5 & 6.15 & 0.62 & 15.4 & 3.5 & 2.78 & ND & 0.15 & 8.3 & $\mathrm{NA}$ & 168.6 & 34.5 \\
\hline & ORF & 1.05 & 10.3 & 26.3 & 2.62 & 3.95 & 0.26 & 26.1 & 2.54 & 1.68 & 5.93 & NA & 172.7 & 28.3 \\
\hline & $S$ & 1.18 & 20.6 & 35.2 & 2.08 & 2.84 & 0.73 & 12.1 & ND & 0.47 & 2.17 & $\mathrm{NA}$ & 105.2 & 10.4 \\
\hline & Genome & 2.68 & 26.4 & 22.5 & 1.78 & 7.39 & 1.5 & 13.7 & ND & 0.77 & 5.47 & $\mathrm{NA}$ & 148.8 & 24.4 \\
\hline \multirow{4}{*}{ 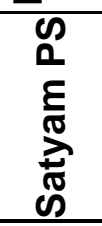 } & $\mathrm{N}$ & 14.1 & 141.7 & 4.91 & 6.48 & 30.4 & 4.88 & 2.23 & 0.21 & 0.28 & 10.2 & 8.21 & 23.2 & 29.5 \\
\hline & ORF & 1.4 & 39.9 & 23 & 24.8 & 10.8 & 1.05 & 17.2 & 3.34 & 2.15 & 7.52 & 5.82 & 13.3 & 27.6 \\
\hline & $S$ & 2 & 78 & 23.3 & 24.8 & 7.01 & 0.36 & 7.09 & 1.69 & 0.51 & 0.68 & 3.03 & 12.1 & 10.3 \\
\hline & Genome & 5.82 & 86.5 & 17.1 & 18.7 & 16.1 & 2.1 & 8.85 & 1.75 & 0.98 & 6.15 & 5.69 & 16.2 & 22.5 \\
\hline \multirow{4}{*}{ 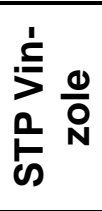 } & $\mathrm{N}$ & 11 & 92.2 & 2.57 & ND & 20.6 & ND & 1.68 & 3.16 & 0.92 & 111.5 & 127.4 & 470.9 & 56.4 \\
\hline & ORF & 3.97 & 22.3 & 34.7 & ND & 6.44 & ND & 16.8 & 34.7 & 6.8 & 43.9 & 187.1 & 1049.2 & 17.1 \\
\hline & $S$ & 6.23 & 51.1 & 37.3 & ND & 4.97 & ND & 5.98 & 11.6 & 2.52 & 18.5 & 105 & 374.5 & 11.7 \\
\hline & Genome & 7.06 & 55.2 & 24.9 & ND & 10.7 & ND & 8.15 & 16.5 & 3.41 & 57.9 & 139.8 & 631.5 & 28.4 \\
\hline \multirow{4}{*}{$\begin{array}{l}\infty \\
0 \\
\frac{\pi}{0} \\
\frac{5}{0} \\
0\end{array}$} & $\mathrm{~N}$ & 38.1 & 427.5 & 5.84 & 1.69 & 22.7 & 0.29 & 2.2 & ND & 1.61 & 155.2 & 305.2 & 249.9 & 401.7 \\
\hline & ORF & 17.9 & 91.4 & 31 & 3.46 & 9.05 & ND & 21.3 & 40.5 & 8.38 & 132.5 & 512.1 & 277.8 & 305.5 \\
\hline & $\mathrm{S}$ & 6.87 & 329.2 & 31.5 & 7.43 & 6.96 & ND & 8.57 & 0.15 & 3.36 & 69.3 & 316.5 & 206.4 & 131.7 \\
\hline & Genome & 20.9 & 282.7 & 22.8 & 4.19 & 12.9 & 5.74 & 10.7 & 0.2 & 4.45 & 119 & 377.9 & 244.7 & 279.6 \\
\hline \multirow{4}{*}{$\sum_{\substack{\infty \\
>}}^{\infty}$} & $\mathrm{N}$ & 13.2 & 110 & 3.12 & 0.87 & 10.3 & 0.8 & 0.22 & 2.02 & 0.46 & 23.9 & 28.5 & 34.7 & 15.2 \\
\hline & ORF & 7.94 & 35.4 & 15.5 & 0.13 & 4.63 & 0.14 & 7.7 & 17.2 & 2.14 & 6.54 & 23.2 & 31.8 & 10.8 \\
\hline & $S$ & 1.33 & 48.7 & 20.2 & 1.01 & 3.01 & ND & 1.09 & 8.56 & 0.76 & 7.93 & 17.5 & 25.3 & 5.62 \\
\hline & Genome & 7.51 & 64.7 & 12.9 & 0.67 & 5.97 & 0.47 & 3 & 9.27 & 1.12 & 12.8 & 23 & 30.6 & 10.5 \\
\hline
\end{tabular}

Low

Where, ND = Not detected; NA = Data not available 
